\title{
Agroecology for Food and Water Security in Times of Climate Consciousness: A Bibliometric Analysis of Peer-Reviewed Literature Published from 1990 to 2020
}

\author{
Tavseef Mairaj Shah *(D), Sumbal Tasawwar and Ralf Otterpohl
}

Citation: Shah, T.M.; Tasawwar, S. Otterpohl, R. Agroecology for Food and Water Security in Times of Climate Consciousness: A Bibliometric Analysis of

Peer-Reviewed Literature Published from 1990 to 2020. Sustainability 2021, 13, 5064. https://doi.org/10.3390/ su13095064

Academic Editors: Maria

Amélia Martins-Loução and

Dawn Sanders

Received: 25 March 2021

Accepted: 29 April 2021

Published: 30 April 2021

Publisher's Note: MDPI stays neutral with regard to jurisdictional claims in published maps and institutional affiliations.

Copyright: (c) 2021 by the authors. Licensee MDPI, Basel, Switzerland. This article is an open access article distributed under the terms and conditions of the Creative Commons Attribution (CC BY) license (https:/ / creativecommons.org/licenses/by/ $4.0 /)$.
Rural Revival and Restoration Engineering (RUVIVAL), Institute of Wastewater Management and Water Protection, Hamburg University of Technology, Eissendorfer Strasse 42, 21073 Hamburg, Germany; sumbal.tasawwar@tuhh.de (S.T.); ro@tuhh.de (R.O.)

* Correspondence: tavseef.mairaj.shah@tuhh.de

\begin{abstract}
The discrepancies in our food systems have become more pronounced in the last couple of years due to natural disasters of huge magnitude and the current pandemic, that have served to make them visible to a wider range of population. As a result, a shift to agroecological food and farming systems is currently being advocated at different levels. An agroecological approach to food systems involves consideration of all their interactions with the major challenges of our time-food security, water scarcity, climate change, socioeconomic disparity. This paper presents a bibliometric study of peer reviewed literature about the role of agroecology in relation to either or all of these challenges, published between 1990 and 2020. 1990 was the year in which IPCC published its first assessment report that set into motion many framework agreements and protocols regarding climate change. In 2019 and 2020, IPBES and iPES-Food released separate reports advocating an urgent agricultural transition based on agroecological methodologies. There has been an exponential increase in the published research in this field in this time period, whereas an overwhelming majority of the publications were filed under the subject areas of agricultural and biological sciences, environmental sciences, and social sciences. In addition to the increasing acceptance of the role of agroecology to address the challenges of our times, the results of this analysis point to the cross-cutting nature of issues agroecology caters to.
\end{abstract}

Keywords: agroecology; food security; water security; bibliometric analysis; data visualization

\section{Introduction}

It is well known that our current food production systems worldwide are not performing to their potential [1-3]. The different hurdles that lie in the pathway of transforming food systems towards sustainability include water scarcity, soil degradation, climate imbalance, and socioeconomic disparities. These challenges affect the lives and livelihoods of both the producers of food (farmers) and the consumers of food [4]. A sustainable food system, while engendering sustainability at and in all levels of the food system, is mainly characterized by its approach to environmental impacts, welfare of the producers, and the nutritional security of the consumers. An important reason of the non-performance of the current food system is the framework in which it is functioning. The current agricultural system is falling short on sustainably ensuring access to enough nutritious food for all and maintaining the socioeconomic well-being of farmers. At the same time, it is driving environmental degradation and loss of biodiversity. This situation calls for a transformation towards more sustainable food systems based on the principles of agroecology [5-7].

Agroecology has been defined as the science of applying ecological concepts and principles to the design and management of sustainable agriculture and food systems [8]. It has been described as a science, a movement, and a practice methodology focused on transforming agriculture into a sustainable and equitable means of production $[3,9]$. 
The agroecological approach to agriculture in general and food security in particular is being widely pushed as the way forward, given the limitations of the current industrial agriculture and the numerous sustainability challenges faced by the food systems. In the last three decades, a wider acceptance of agroecological interventions has led to projects being undertaken in different parts of the world with the aim of researching the potential of agroecology in achieving the goals of food security, sustainable development, and biodiversity protection while at the same time giving due consideration to the aims of the global climate agreements [9-13].

The success of agroecological interventions in different projects around the world has led to an organic spread of such methodologies. The spread of an alternate methodology of rice farming called the System of Rice Intensification (SRI), an agroecological methodology, exemplifies this. SRI started off as a group of individual rice farming practices in response to declining soil quality and plummeting yields in the rice farms of Madagascar in 1970s [14-16]. Fifty years down the line, SRI applications can be found in all the major rice producing countries of the world. The sustainable nature of SRI in terms of its low input, water saving, weather resilience, and high yielding nature have made it an important part of the transformation of rice farming onto a sustainable pathway [17-19]. Dissemination of the methodology and results through scientific publications also plays a role in the spread of such innovations, as universities and research institutes can play a vital role in the agricultural extension and farmer participative experiments [20-22]. This review examines the role of published scientific literature in the intersectional field of agroecology, food and water security, biodiversity, and sustainable development in view of the different framework conventions and protocols that came into existence in the last three decades - a time period the authors call the age of climate consciousness-by means of a bibliometric analysis.

The time period chosen for this bibliometric analysis is 1990 to 2020. This time period was chosen as IPCC released its first assessment report in 1990, which set into motion different international climate treaties and protocols focusing on climate action [23]. The Millennium Summit of the United Nations in 2000 resulted in setting aim at the eight Millennium Development Goals (MDGs), which were succeeded by the seventeen Sustainable Development Goals (SDGs) in 2015 as part of the agenda 2030. At least 11 of these 17 SDGs are covered under the purview of this analysis, linked to food and water security [4,24-27]. The disruption in the food systems caused during the COVID19 pandemic further highlighted the discrepancies of the food system and prompted policymakers to look for alternatives [28-31]. The 2021 UN Food Systems Summit is a step in this direction, to look for alternate ways for our food systems [29]. In this regard, the emergency iPES-Food communique at the (then) peak of the COVID-19 pandemic from April 2020 titled 'COVID-19 and the crisis in food systems: Symptoms, causes, and potential solutions' and the IPBES 'Global Assessment Report on Biodiversity and Ecosystem Services' released in 2019 highlight the role agroecology can play in the transition to sustainable food systems worldwide $[5,6]$. This review aims to be reference in that direction with an analysis on the different aspects of published research in this field [5,6,25,32].

\section{Materials and Methods}

The data were generated using the online Scopus database as it was found to be more extensive than other available databases like PubMed and Web of Science, as also reported in literature. The most common keywords found in the literature relevant to the field of interest were as follows: food security, food system, water, agroecology, climate change, sustainable farming, malnutrition, poverty, rural development, sustainable development, environmental degradation, environmental impact, hunger, transformation, transition, resources, and biodiversity. The logic behind the selection of the keywords to be used in the search query was based on their general occurrence in literature and their relevance to the thematic area of this paper. However, in order to narrow down the selection of keywords and to establish a comprehensive search term, the following logic was designed: 
Challenge: Climate change

Manifestations: Weather/Environmental degradation/Environmental impact

Problems: Poverty/Hunger/Malnutrition

System: Food system/Water system/Rural development/Natural resources

Solutions: Sustainable agriculture/Food security/Sustainable development

Plus: Bodiversity, Social balance, Economic prosperity, Healthy communities

Framework solution: Agroecology; Transition/Transformation

Database: Scopus

Based on the logic stated above the search query developed was as follows:

TITLE-ABS-KEY ('Agroecolog *' AND 'climate' OR 'weather OR environment OR degradation' AND 'sustainable OR farming OR food OR development' OR 'food system OR water

OR rural OR resource' OR 'poverty OR hunger OR nutrition' OR 'diversity OR health OR social OR economic') AND PUBYEAR > 1990 PUBYEAR < 2021

The search string has been written in such a way that the results include references to agroecology as a must. As a result, following the search logic of Scopus, the letter $y$ at the end of the word 'agroecology' was replaced by an asterisk in order to accommodate all the search results with terms 'agroecology' and 'agroecological'. The Boolean operators AND and OR are used as is known in common parlance.

\section{Results and Discussions}

The search query retrieved 1974 documents for the time period between 1990 and 2020. The number of publications over the last three decades in this field has been increasing at an exponential rate, with the slope being even steeper in the last few years. The number of documents for the years 2018, 2019, and 2020 was 211, 210, and 291 respectively (Figure 1)

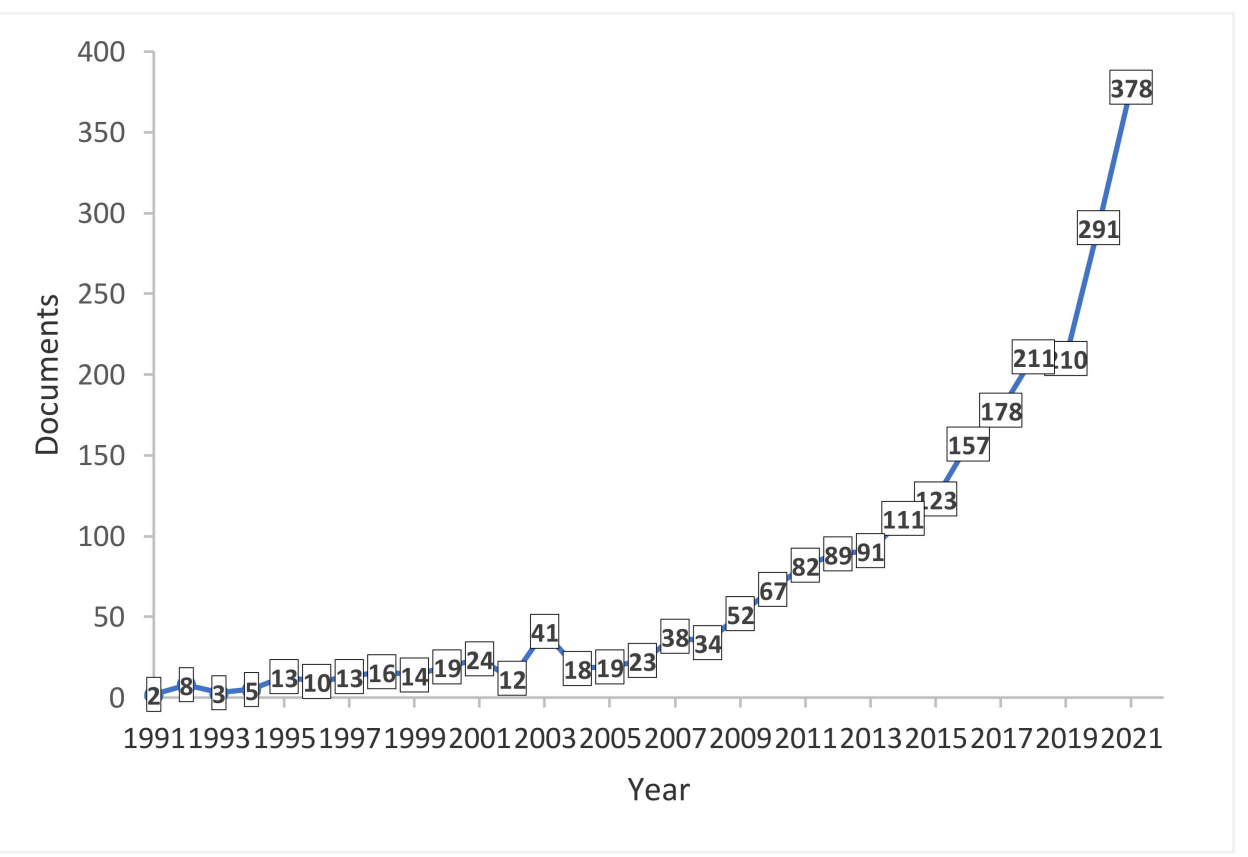

Figure 1. The yearly number of documents published from 1991 to 2020 .

\subsection{Type of Publication}

The expected number of documents for the year 2021 was predicted on the basis of linear regression, with 87 documents having been published in the first twelve weeks of 2021, which approximates to 378 for 52 weeks. The retrieved documents were mainly research articles $(\mathrm{n}=1482 ; 75 \%)$ followed by review articles $(\mathrm{n}=217 ; 11 \%)$ and book chapters $(n=146 ; \%)$ (Figure 2). This hints at the fact that the type of published research in agroecological and related fields is original research work hence the increasing spread of agroecological interventions can be deduced. In total, the search returned documents in 
fourteen different language with English clearly being the main language of communication ( $\mathrm{n}=1823 ; 92.35 \%$ ), with Spanish, Portuguese, French, and Chinese being distant next in line languages of communication with $53,46,39$, and 20 documents to their name respectively.

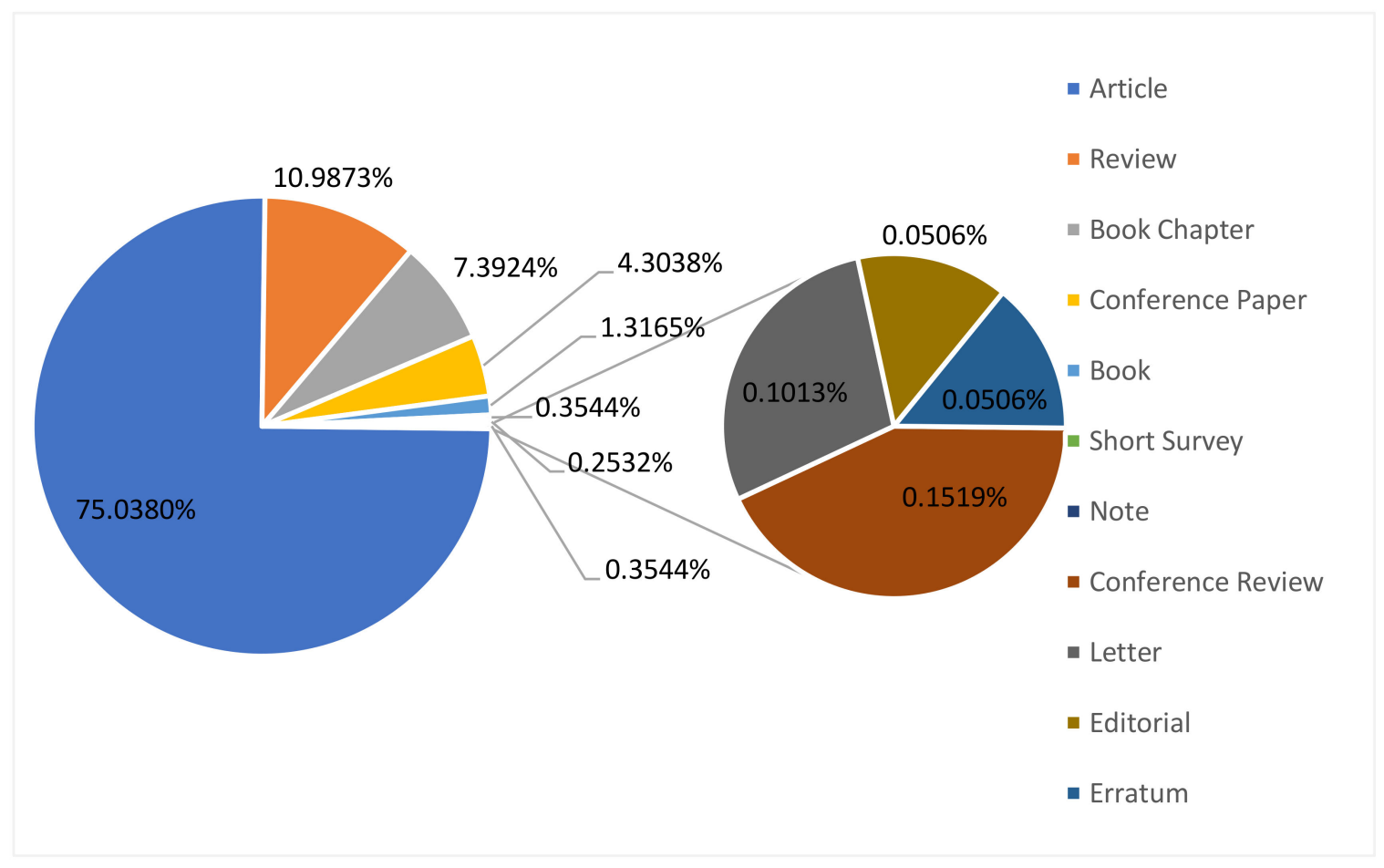

Figure 2. A break-up of the documents based on the type of publication.

\subsection{Subject Areas}

In terms of subject areas, documents from up to 25 subject areas were returned in the search out of which the top 10 are listed in the table (Table 1). There are two percentage values given in the table; absolute and relative. The absolute percentage gives the absolute values of the percentage of documents that have been assigned to a particular subject area. In calculating the absolute percentage, the reference number is the total number of documents. In case of the relative percentage, the reference number is the total number if incidences, i.e., the total number of times a document is assigned to one of the listed subject areas. The following example can be a guide for the reader to make sense of the two percentage values in the table. A total of $45 \%$ papers fall under the subject area of 'Environmental Science', however some of these papers may also fall under another subject area due to its interdisciplinary nature. Hence the sum of percentages of the 10 subject areas listed can be well over 100. The subject area wise distribution of the research papers can give the reader an idea about the wide-ranging relevance of agroecological interventions in the current times. It can be seen that the subject area of Agricultural and Biological Sciences as defined in Scopus is the subject area to which most of the publications are attributed to. This is expected given the close relation of the major themes of food security, water security, and rural development to this subject area. The presence of environmental science and social sciences as the second and third ranking subject areas points to the cross-sectional importance of addressing the challenges of food and water security, climate action and sustainable development on one hand and the interdisciplinary role agroecology-based interventions can play in addressing these challenges. 
Table 1. A list of the top 10 subject areas covering the documents.

\begin{tabular}{ccccc}
\hline Rank & Subject Area & Frequency & Absolute \% (T= 1974) & Relative \% (N = 3671) \\
\hline 1 & Agricultural and Biological Sciences & 1155 & 58.5 & 31.5 \\
2 & Environmental Science & 889 & 45.0 & 24.2 \\
3 & Social Sciences & 549 & 27.8 & 14.9 \\
4 & Earth and Planetary Sciences & 205 & 10.4 & 5.6 \\
5 & Energy & 179 & 9.1 & 4.9 \\
6 & Engineering & 123 & 6.2 & 3.4 \\
7 & Biochemistry, Genetics and & 112 & 5.7 & 3.1 \\
8 & Molecular Biology & 98 & 4.9 & 2.7 \\
9 & Economics, Econometrics and Finance & 55 & 2.8 & 1.5 \\
10 & Arts and Humanities & 48 & 2.4 & 1.3 \\
\hline
\end{tabular}

A total of 5438 different keywords were linked to the documents that the search returned. In order to narrow down the number of keywords to a meaningful minimum, a threshold was established. Only keywords with a minimum number of occurrences of a greater or equal to 19 were included for the visualization: only 29 passed the threshold. In Figure 3, the top 29 keywords are visualized as a network map with the help of VOSviewer software (trial version) from the Centre for Science and Technology Studies, Leiden University, The Netherlands [33]. The following network visualization gives an idea about the research papers published in the time period 1990 to 2020, whose subject area lay at the intersection of the topics of agroecology, sustainable development, food security, and climate change.

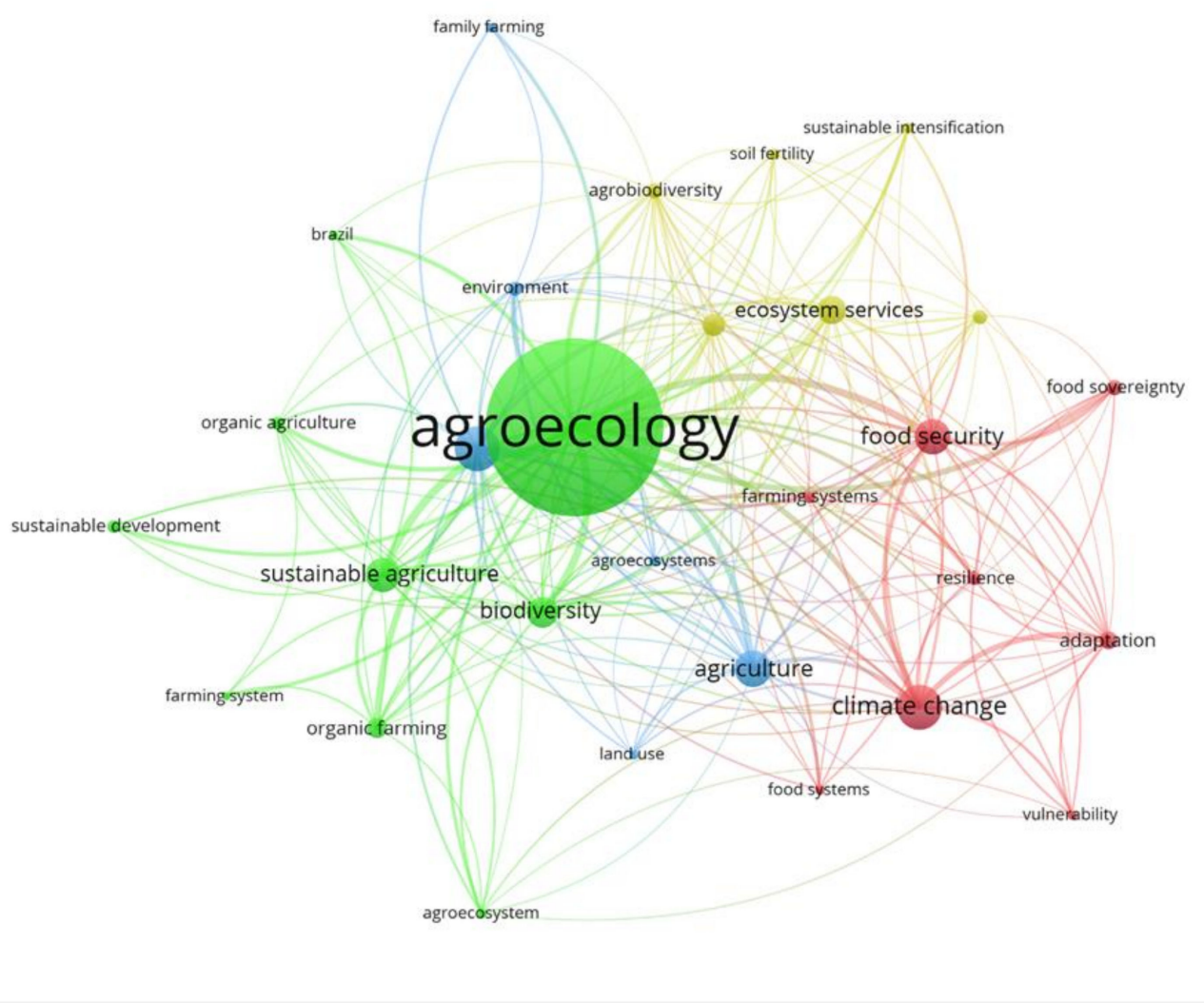

Figure 3. A network visualization of the main keywords found in the search results. 


\subsection{Research Themes}

The network visualization in Figure 3 points to the positioning of agroecology as a central theme in the academic sustainability discourse around the topics of food security, water scarcity, and climate change. The fact that agroecology links with food security, climate change, biodiversity, and ecosystem services at the same time highlights the potential of agroecological interventions with respect to addressing these challenges that has been reported in published scientific literature in the last 30 years.

\subsection{Geographical Distribution}

The bibliometric search returned published documents from at least 138 countries, from East Timor to Yemen and Afghanistan to Peru, with a total of 34 documents being of 'undefined' source (nationality). The top 10 countries based on the published research output in the research fields under consideration are presented in tabulated form, with the US topping the list with 506 documents, followed by 266 documents from France, and 163 from the UK (Figure 4). The search results returned with 50 countries with at least 10 documents. These numbers point to a widespread understanding and application of agroecological methodologies for food security in the backdrop of climate change in almost every country of the world.

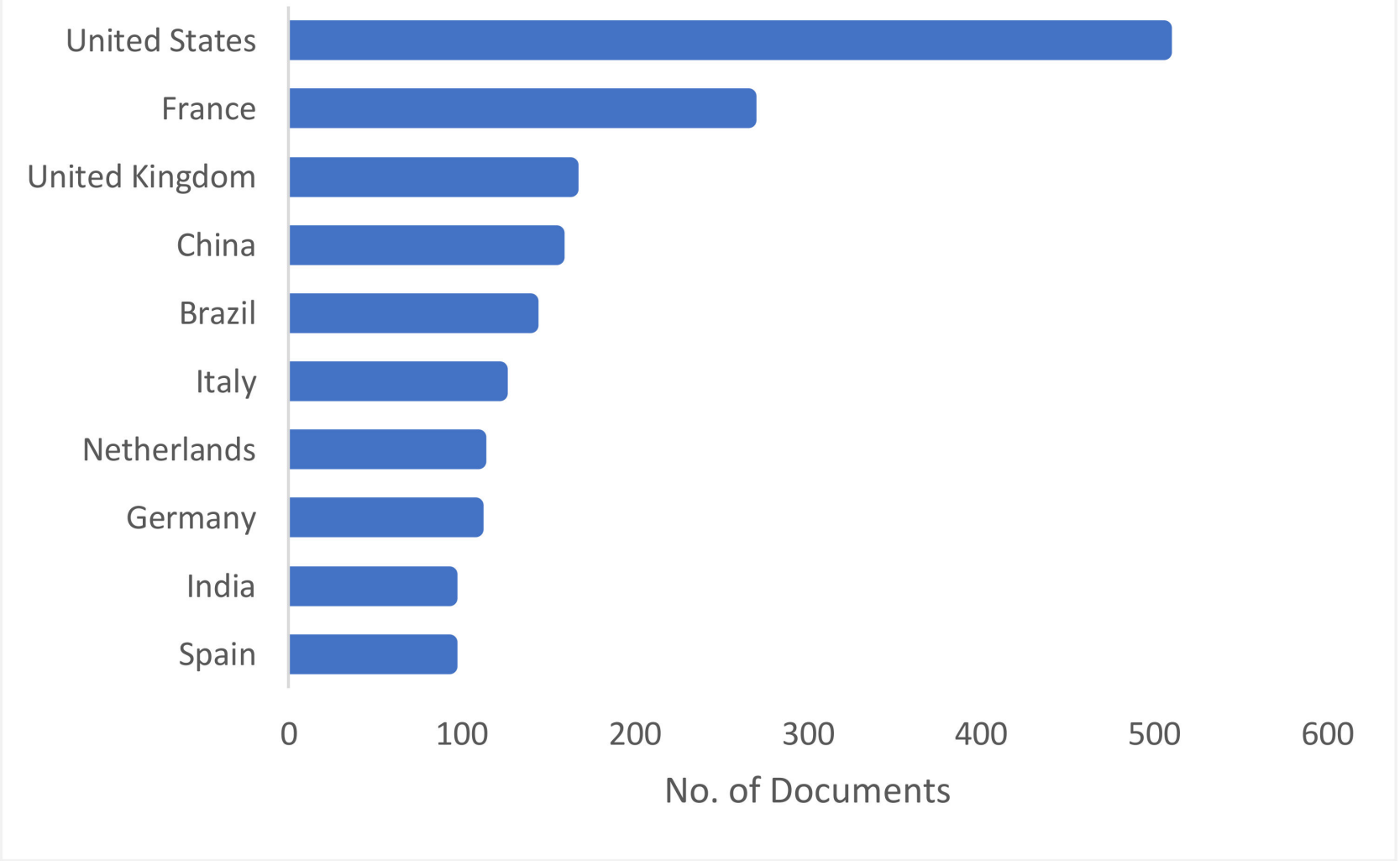

Figure 4. A list of the top 10 countries in terms of research output.

\subsection{Top Authors}

A list of the top authors with at least 8 documents to their name in the search results is presented in Figure 5. The list is topped by Prof. Charles A. Francis and Prof. Miguel A. Altieri. Prof. Altieri is the author of the books 'Agroecology: The Science of Sustainable Agriculture' (1987) and 'Agroecology and the Search for a Truly Sustainable Agriculture' (2005). A significant name in the list is Prof. Norman Uphoff, who is credited with much of work 
behind the success of the System of Rice Intensification (SRI) all over the world. The analysis takes into account all authors and affiliations not just the principal/corresponding authors.

\section{Francis C.A.}

\section{Altieri M.A.}

Wezel A.

Dumont B.

Uphoff N.

Canali S.

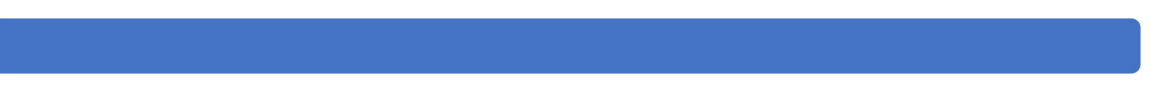

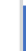

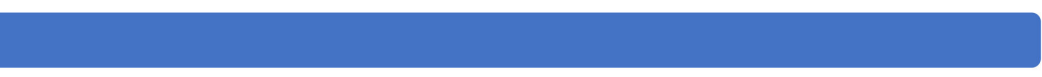

Duru M.

Snapp S.S.
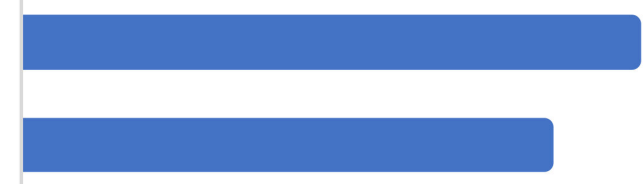

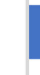
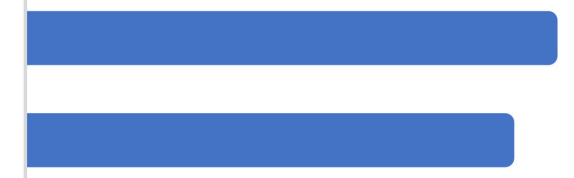

$0 \quad 5 \quad 10$

15

20

25

No. of Documents

Figure 5. A list of top authors in terms of research output.

\subsection{Institutional Affiliation}

A list of the top 10 research entities worldwide based on the number of publications in the research field under consideration is presented in Figure 6. A clear frontrunner in this field is Wageningen University and Research from Netherlands with the other two top spots occupied by two other European research entities. This makes for an interesting reading. While as the US leads the country wise distribution of research output in this field, the institute wise distribution is dominated by non-US research entities. However, as with the author's list, in the institute list as well, the name associated with SRI, Cornell University occupies the fifth place. This can again be attributed to the widespread research being done in the agroecological methodology of rice cultivation, the System of Rice Intensification. Cornell University is home to the SRI International Network and Resources Center (SRI-RICE). 
Wageningen University \& Research

INRAE

CIRAD Centre de Recherche de Montpellier

Chinese Academy of Sciences

Cornell University

AgroParisTech

INRAE Occitanie-Toulouse

University of California, Berkeley

Michigan State University

Agroécologie, Innovations, teRritoires - AGIR

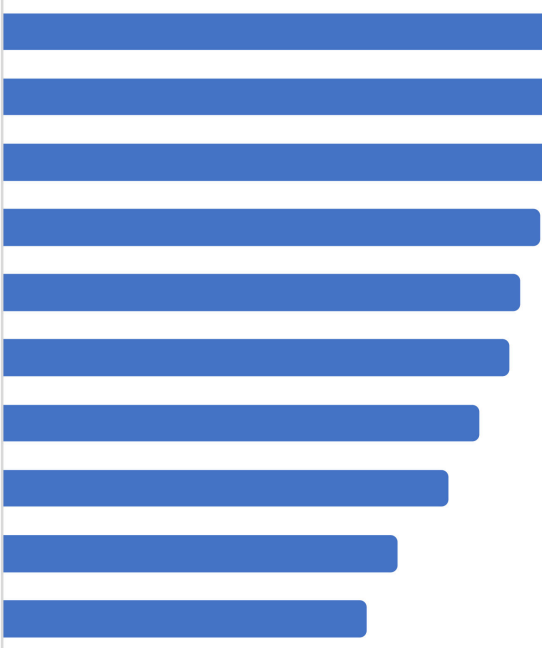

0

$\begin{array}{lllll}10 & 20 & 30 & 40 & 50\end{array}$

No. of Documents

Figure 6. A list of top 10 universities or research institutes based on affiliated research output.

\section{Conclusions}

This bibliometric study gives an insight into the state and trajectory of published research in the field of 'agroecology for food and water security in the backdrop of climate change on the path to sustainable development'. The different parameters analyzed in this study point to an increasing interest and application of agroecological practices all over the world evident from publication output from more than 100 countries of the world, including the least developed countries as well as countries in a state of war. The United States leads the list of countries in terms of research output while European institutions like Wageningen University, INRAE, and CIRAD are the leading research entities in this field of research. The System of Rice Intensification seems to play a leading role in agroecological research and impact, which can be deduced from the presence of Prof. Norman Uphoff and his Cornell University in the top five of the author list and institute lists in terms of publication output. This bibliometric analysis points to the cross-sectorial role agroecological farming systems can play in contributing towards addressing the pressing issues of our times-food and water security, climate change, socioeconomic disparities.

Author Contributions: Conceptualization, T.M.S. and S.T.; methodology, T.M.S.; software, T.M.S.; validation, S.T.; resources, R.O.; writing-original draft preparation, T.M.S.; writing-review and editing, S.T.; visualization, T.M.S.; supervision, R.O.; project administration, R.O. All authors have read and agreed to the published version of the manuscript.

Funding: We acknowledge support for the Open Access fees by Hamburg University of Technology (TUHH) in the funding programme Open Access Publishing.

Institutional Review Board Statement: Not applicable.

Informed Consent Statement: Not applicable.

Data Availability Statement: Not applicable.

Conflicts of Interest: The authors declare no conflict of interest. 


\section{References}

1. Webb, N.P.; Marshall, N.A.; Stringer, L.C.; Reed, M.S.; Chappell, A.; Herrick, J.E. Land degradation and climate change: Building climate resilience in agriculture. Front. Ecol. Environ. 2017, 15, 450-459. [CrossRef]

2. Kumar, M.D.; Sivamohan, M.V.K.; Narayanamoorthy, A. The food security challenge of the food-land-water nexus in India. Food Secur. 2012, 4, 539-556. [CrossRef]

3. Wezel, A.; Casagrande, M.; Celette, F.; Vian, J.F.; Ferrer, A.; Peigné, J. Agroecological practices for sustainable agriculture. A review. Agron. Sustain. Dev. 2014, 34, 1-20. [CrossRef]

4. Pérez-Escamilla, R. Food Security and the 2015-2030 Sustainable Development Goals: From Human to Planetary Health. Curr. Dev. Nutr. 2017, 1, e000513. [CrossRef]

5. IPES-Food. COVID-19 and the Crisis in Food Systems: Symptoms, Causes, and Potential Solutions; IPES-Food: Brussels, Belgium, 2020.

6. Biodiversity centre stage. Nat. Ecol. Evol. 2019, 3, 861. [CrossRef] [PubMed]

7. Leippert, F.; Darmaun, M.; Bernoux, M.; Mpheshea, M. The Potential of Agroecology to Build Climate-Resilient Livelihoods and Food Systems; Food and Agriculture Organization of the United Nations FAO and Biovision: Rome, Italy, 2020.

8. Francis, C.; Lieblein, G.; Gliessman, S.; Breland, T.A.; Creamer, N.; Harwood, R.; Salomonsson, L.; Helenius, J.; Rickerl, D.; Salvador, R.; et al. Agroecology: The ecology of food systems. J. Sustain. Agric. 2003, 22, 99-118. [CrossRef]

9. Wezel, A.; Bellon, S.; Doré, T.; Francis, C.; Vallod, D.; David, C. Agroecology as a science, a movement and a practice. A review. Agron. Sustain. Dev. 2009, 29, 503-515. [CrossRef]

10. Abraham, B.; AdeOluwa, O.O.; Araya, H.; Berhe, T.; Bhatt, Y.; Edwards, S.; Gujja, B.; Khadka, R.B.; Koma, Y.S.; Sen, D.; et al. The System of Crop Intensification Agroecological Innovations for Improving Agricultural Production, Food Security, and Resilience to Climate Change; SRI International Network and Resources Center (SRI-Rice): Ithaca, NY, USA, 2014; ISBN 9789290815495.

11. Uphoff, N. Agroecological Implications of the System of Rice Intensification (SRI) in Madagascar. Environ. Dev. Sustain. 1999, 1, 297-313. [CrossRef]

12. Stoop, W.A.; Pushpalatha, S.; Ravindra, A.; Debashish, S.; Prasad, S.C.; Thakur, A.K. Opportunities for ecological intensification Lessons and insights from the System of rice/crop intensification-Their implications for agricultural research and development approaches. CAB Rev. Perspect. Agric. Vet. Sci. Nutr. Nat. Resour. 2017, 12, 1-19. [CrossRef]

13. Moberg, F.; Höök, K.; Salomonsson, L.; Mastroianni, K.; Lundberg, J.; Karlberg, L.; Rundgren, G. How to Feed Nine Billion within the Planet's Boundaries: The Need for an Agroecological Approach; Moberg, F., Ed.; Stockholm Environment Institute: Stockholm, Sweden, 2015.

14. Uphoff, N. SRI: An agroecological strategy to meet multiple objectives with reduced reliance on inputs. Agroecol. Sustain. Food Syst. 2017, 41, 825-854. [CrossRef]

15. Khumairoh, U.; Groot, J.C.J.; Lantinga, E.A. Complex agro-ecosystems for food security in a changing climate. Ecol. Evol. 2012, 2, 1696-1704. [CrossRef]

16. Adhikari, P.; Araya, H.; Aruna, G.; Balamatti, A.; Banerjee, S.; Baskaran, P.; Barah, B.C.; Behera, D.; Berhe, T.; Boruah, P.; et al. System of crop intensification for more productive, resource-conserving, climate-resilient, and sustainable agriculture: Experience with diverse crops in varying agroecologies. Int. J. Agric. Sustain. 2017, 5903, 1-28. [CrossRef]

17. Gathorne-Hardy, A.; Reddy, D.N.; Venkatanarayana, M.; Harriss-White, B. System of Rice Intensification provides environmental and economic gains but at the expense of social sustainability-A multidisciplinary analysis in India. Agric. Syst. 2016, 143, 159-168. [CrossRef]

18. Thakur, A.K.; Kassam, A.; Stoop, W.A.; Uphoff, N. Modifying rice crop management to ease water constraints with increased productivity, environmental benefits, and climate-resilience. Agric. Ecosyst. Environ. 2016, 235, 101-104. [CrossRef]

19. Shah, T.M. Agroecological Engineering Interventions for Food Security and Sustainable Rural Development: The Case of Rice Farming in Kashmir, 103rd ed.; Gesellschaft zur Förderung der Forschung und Entwicklung der Umwelttechnologien (GFEU) an der Technischen Universität Hamburg e.V.: Hamburg, Germany, 2021; ISBN 9783942768283.

20. Barrett, K.R. Ecological engineering in water resources: The benefits of collaborating with nature. Water Int. 1999, 24, 182-188. [CrossRef]

21. Vörösmarty, C.J.; Pahl-Wostl, C.; Bunn, S.E.; Lawford, R. Global water, the anthropocene and the transformation of a science. Curr. Opin. Environ. Sustain. 2013, 5, 539-550. [CrossRef]

22. Noltze, M.; Schwarze, S.; Qaim, M. Understanding the adoption of system technologies in smallholder agriculture: The system of rice intensification (SRI) in Timor Leste. Agric. Syst. 2012, 108, 64-73. [CrossRef]

23. Lee, H. Statement on the 30th Anniversary of the IPCC First Assessment Report; IPCC: Geneva, Switzerland, 2020.

24. Keesstra, S.D.; Bouma, J.; Wallinga, J.; Tittonell, P.; Smith, P.; Cerdà, A.; Montanarella, L.; Quinton, J.N.; Pachepsky, Y.; Van Der Putten, W.H.; et al. The significance of soils and soil science towards realization of the United Nations sustainable development goals. Soil 2016, 2, 111-128. [CrossRef]

25. Rasul, G. Managing the food, water, and energy nexus for achieving the Sustainable Development Goals in South Asia. Environ. Dev. 2016, 18, 14-25. [CrossRef]

26. Bouma, J. Soil science contributions towards Sustainable Development Goals and their implementation: Linking soil functions with ecosystem services. J. Plant Nutr. Soil Sci. 2014, 177, 111-120. [CrossRef]

27. Doelman, J.C.; Stehfest, E.; Tabeau, A.; van Meijl, H. Making the Paris agreement climate targets consistent with food security objectives. Glob. Food Sec. 2019, 23, 93-103. [CrossRef] 
28. UNSCN. The COVID-19 Pandemic Is Disrupting People's Food Environments: A Resource List on Food Systems and Nutrition Responses. Available online: https: / / www.unscn.org/en/news-events/recent-news?idnews=2039 (accessed on 21 April 2021).

29. Carducci, B.; Keats, E.C.; Ruel, M.; Haddad, L.; Osendarp, S.J.M.; Bhutta, Z.A. Food systems, diets and nutrition in the wake of COVID-19. Nat. Food 2021, 2, 68-70. [CrossRef]

30. Savary, S.; Akter, S.; Almekinders, C.; Harris, J.; Korsten, L.; Rötter, R.; Waddington, S.; Watson, D. Mapping disruption and resilience mechanisms in food systems. Food Secur. 2020, 12, 695-717. [CrossRef] [PubMed]

31. Harris, J.; Depenbusch, L.; Pal, A.A.; Nair, R.M.; Ramasamy, S. Food system disruption: Initial livelihood and dietary effects of COVID-19 on vegetable producers in India. Food Secur. 2020, 12, 841-851. [CrossRef] [PubMed]

32. IPBES Intergovernmental Science-Policy Platform on Biodiversity and Ecosystem Services. Thematic Assessment of Land Degradation and Restoration; Agenda Item 7; IPBES Intergovernmental Science-Policy Platform on Biodiversity and Ecosystem Services: Bonn, Germany, 2018.

33. Leiden University. VOSviewer-Visualising Scientific Landscapes. Available online: https://www.vosviewer.com/download (accessed on 21 April 2021). 